\title{
Barriers to Building Information Modeling (BIM) implementation in China's prefabricated construction: An interpretive structural modeling (ISM) approach
}

\author{
Tan Tan ${ }^{1}, \mathrm{Ke} \mathrm{Chen}^{2}$, Fan $\mathrm{Xue}^{3}$, and Weisheng $\mathrm{Lu}^{4}$
}

This is the peer-reviewed post-print version of the paper:

Tan, T., Chen, K., Xue, F., \& Lu, W. (2019). Barriers to Building Information Modeling (BIM) implementation in China's prefabricated construction: An interpretive structural modeling (ISM) approach. Journal of Cleaner Production, In press, published online. Doi: 10.1016/j.jclepro.2019.02.141

The final version of this paper is available at: https://doi.org/10.1016/j.jclepro.2019.02.141. The use of this file must follow the Creative Commons Attribution Non-Commercial No Derivatives License, as required by Elsevier's policy.

\section{Highlights}

- Barriers affecting BIM implementation in China's prefabricated construction were identified.

- The interrelationships among key barriers were analyzed.

- ISM methodology was applied to evaluate most influential relationships.

- Recommendations for BIM implementation in China's prefabricated construction were provided.

\begin{abstract}
It is widely recognized that Building Information Modeling (BIM) can facilitate the delivery of prefabricated construction. Nevertheless, the actual practice of BIM faces several barriers. A range of existing studies and literature have discussed these barriers extensively, but two research questions remain unanswered. First, what are the unique barriers facing the use of BIM in China's prefabricated construction? Second, how do these barriers interrelate with one another? This research aims to address these two questions. Conducting a two-round literature review and a questionnaire survey ascertained twelve barriers acutely affecting the Chinese experience of applying BIM to prefabricated construction. In addition, Interpretive Structural Modeling (ISM) was used to identify interrelationships among these barriers. The exercise found that, compared with the cost-related issues suggested by previous studies that focused on general BIM implementation barriers, the lack of research about BIM in China and the absence of standards and domestic-oriented tools are likely the biggest hindrances to
\end{abstract}

\footnotetext{
${ }^{1}$ Research Assistant, Department of Real Estate and Construction, The University of Hong Kong, Hong Kong, e-mail: tan.tan.17@ucl.ac.uk;

2 Associate Professor, Corresponding Author, Department of Construction Management, School of Civil Engineering and Mechanics, Huazhong University of Science and Technology, e-mail: chenkecm@hust.edu.cn, Tel.: 86-15342200726;

${ }^{3}$ Research Assistant Professor, Department of Real Estate and Construction, The University of Hong Kong, Hong Kong, email: xuef@hku.hk;

${ }^{4}$ Associate Professor, Department of Real Estate and Construction, The University of Hong Kong, Hong Kong, e-mail: wilsonlu@hku.hk; 
the practical application of BIM in China's prefabricated construction. This study contributes to the knowledge body by revealing major barriers to BIM implementation in China's prefabricated construction and crafting a corresponding three-level strategy to facilitate the possible implementation. The findings of this study can thus act as a practical reference for future research attempting to provide technological and managerial solutions to improve BIM implementation in China's prefabricated construction.

Keywords: prefabricated construction; building information modeling; barrier; interpretive structural modeling; China

\section{Introduction}

Since the recovery of the 2008 financial crisis, many developing countries have experienced a resurgence of interest in prefabricated construction in order to meet growing demands for new housing and infrastructure ( $\mathrm{Lu}$ et al., 2018). China is no exception. Since the late 1990s, China's construction sector has seriously needed to enhance the overall performance of its construction projects. Against this backdrop, the development of prefabricated construction accelerated in China (Hong et al., 2018). Unlike traditional cast-in-situ methods, prefabricated construction produces building components at a manufacturing facility and then transports entire components or semi-components to the construction site for assembly (Tam et al., 2007). Although its adoption at times can increase construction costs (Lu and Yuan, 2013), prefabricated construction has been endorsed as a 'cleaner' approach due to its ability to reduce construction waste, noise, dust, labor demand, and resource depletion, as well as increase safety management (Jaillon and Poon, 2009; Lu et al., 2018).

The advent of Building Information Modeling (BIM) offers new opportunities to further harness the efficiency of prefabricated construction. BIM is a digital representation of a constructed facility (Eastman et al., 2011) and offers an important line of 'integration' (Chen et al., 2015), which is likewise critical for the delivery of prefabricated construction. Li et al. (2017) mitigated scheduling risks in prefabricated construction by integrating BIM and RFID. Chen et al. (2018) also introduced a physical internet-enabled BIM platform to improve efficiency of resource management and decrease human errors in prefabricated construction. More studies on BIM and RFID integration can be seen from Xue et al. (2018). Nevertheless, the actual deployment and implementation of BIM in prefabricated construction are still few and far between (Papadonikolaki and Aibinu, 2017). The benefits of BIM remain rhetorical without appropriately addressing some critical barriers. This has prompted several studies to investigate barriers to BIM implementation, which include but not limited to the high front-end cost of BIM implementation (Azhar et al, 2011), the insufficient understanding of current organizations' readiness to adopt BIM (Khosrowshahi and Arayici, 2012), and the lack of common BIM standards to facilitate BIM adoption and 
implementation (Nawari, 2012).

Several previous studies have analyzed barriers to the implementation of BIM and prefabrication on their own (e.g., Jin et al., 2017; Jiang et al., 2018), and a few have provided valuable information concerning the barriers that hinder BIM implementation in the deployment of prefabricated construction. For example, Jin et al. (2018) noticed a number of managerial barriers that occur widely when applying BIM to off-site construction based on a holistic review. However, two issues have been overlooked. First, previous studies did not investigate the unique BIM implementation barriers to prefabricated construction within the context of China, which is a huge and heterogeneous market. Second, these studies neglected to acknowledge the fact that different types of barriers are not isolated, but rather form complex correlations in impeding successful BIM implementation. By neglecting the interrelationships between BIM implementation barriers, the existing research has failed to identify the high-priority obstacles and develop sensible strategies to promote BIM implementation in prefabricated construction (Tan, 2018).

This study thus aims to investigate the implementation barriers of BIM and their interrelationships in the context of China's prefabricated construction. Three objectives are to be achieved: (1) to discover the possible barriers to BIM implementation in China's prefabricated construction; (2) to assess the interrelationships between these barriers; and (3) to prioritize these barriers based on their interrelationships. The objectives are achieved by devising a mixed method approach with the Interpretive Structural Modeling (ISM) as the kernel. Key barriers with their interrelationships are determined and analyzed in depth. Based on the identification of high-priority barriers, implications on the BIM implementation in China's prefabricated construction are discussed.

\section{Research Methods}

This study follows a three-step research design to achieve the objectives of this research (see Figure 1). First, a preliminary identification of barriers that could affect BIM implementation in China's construction industry was prepared by a two-round systematic literature review. Next, a questionnaire survey with industrial practitioners was carried out in order to filter the barriers that specifically affect BIM implementation in prefabricated construction in China. The final step was to develop an ISM-based model to analyze the interrelationships between the identified barriers. In this step, semi-structured interviews with construction professionals were undertaken to source expert opinions about such relationships among barriers. The expert opinions were then ordered hierarchically and logically using ISM and MICMAC (Matrice d'Impacts Croisés Multiplication Appliquée à un Classement). 


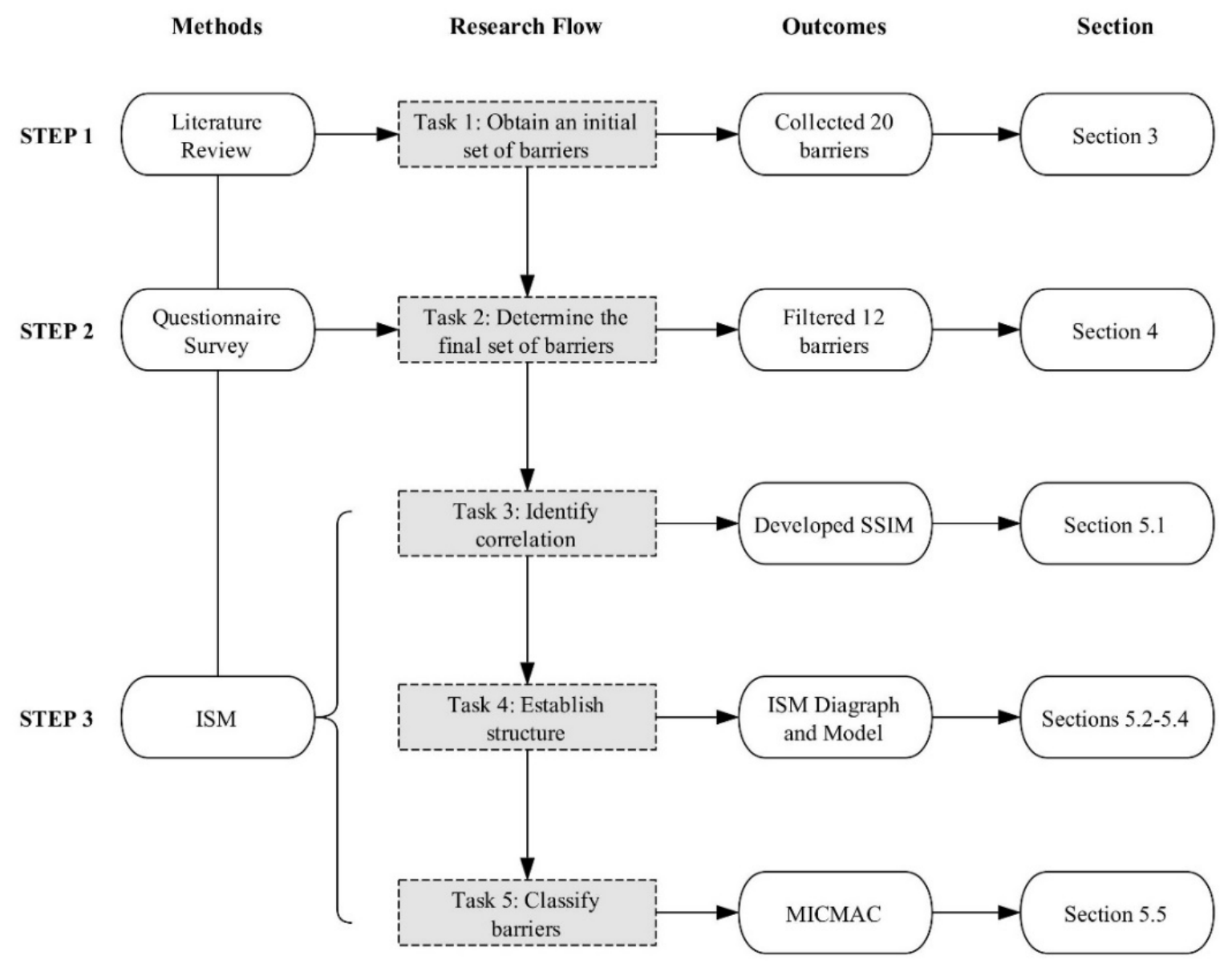

Figure 1 Research flow

\section{Preliminary Identification of Possible Barriers}

The literature review in this study was carried out over two rounds. In the first round, keywords, including "barrier", "building information model*" (* denotes fuzzy search) and "prefabrication" or other terms related to prefabrication, such as "prefabricated construction", "precast", and "offsite construction", were entered to find relevant literature in the database of Google Scholar. However, only a limited amount of studies specifically investigating barriers to BIM implementation in prefabricated construction were located. In this preliminary research step, it is necessary to identify as many potential BIM implementation barriers as possible. Thus, a second round of literature review was performed to identify all BIM implementation barriers that arise in all types of construction projects. Keywords used for the second-round include "barrier" and "building information model*" (* denotes fuzzy search). For a comprehensive literature search, in both rounds of literature review, the same keywords were used to collect relevant papers from two different databases, i.e., ISI Web of Science and Scopus. After the two-round literature review, the authors screened each of the collected papers and recorded the key barriers described. Based on the frequency of occurrence and factor diversification, twenty barriers that could affect BIM implementation in China's construction industry were collected and then divided into five main categories (see Table 1). Each is briefly described as follows. 
Table 1 Category of potential barriers

\begin{tabular}{|c|c|c|c|}
\hline Category & Barrier & Key References and Frequency of Occurrenc & \\
\hline \multirow{3}{*}{ Technical } & $\begin{array}{l}\text { B01 Difficulty in Adapting to the } \\
\text { BIM Technology and Process }\end{array}$ & $\begin{array}{l}\text { Yan and Damian, 2008; Lu and Korman, } \\
\text { 2010; He et al., 2012; Rezguil et al., 2013; } \\
\text { Zhang et al., 2013; Elmualim and Gilder, } \\
\text { 2014; Rogers et al., 2015; Xu and Kong, 2016; } \\
\text { Jin et al., } 2017\end{array}$ & 9 \\
\hline & $\begin{array}{l}\text { B02 Lack of Domestic-oriented } \\
\text { BIM Tools }\end{array}$ & $\begin{array}{l}\text { Tse et at., 2005; Pan and Zhao, 2012; He et al., } \\
\text { 2012; Zhang et al., 2013; Xu and Kong, 2016; } \\
\text { Bui et al., 2016; Zhang et al., } 2016\end{array}$ & 7 \\
\hline & $\begin{array}{l}\text { B03 Increased Workload for } \\
\text { Model Development }\end{array}$ & $\begin{array}{l}\text { Azhar et al., 2012; Pan and Zhao, 2012; Zhang } \\
\text { et al., 2013; Liu and Liu, 2015; Zhao et al., } \\
2018\end{array}$ & 5 \\
\hline \multirow{6}{*}{ Management } & B04 Resistance to Change & $\begin{array}{l}\text { Yan and Damian, 2008; Gu and London, 2010; } \\
\text { Eastman et al., 2011; Arayici et al., 2011; } \\
\text { Panuwatwanich and Peansupap, 2013; Zhang } \\
\text { et al., 2013; Stanley and Thurnell, 2014; Xu et } \\
\text { al., 2014; Liu and Liu, 2015; Xu and Kong, } \\
\text { 2016; Mehran, } 2016\end{array}$ & 11 \\
\hline & $\begin{array}{l}\text { B05 Negative Attitude towards } \\
\text { Data Sharing }\end{array}$ & $\begin{array}{l}\text { Dossick and Neff, 2010; Azhar, 2011; Rezguil } \\
\text { et al., 2013; Won et al., 2013; Stanley and } \\
\text { Thurnell, 2014; Liu and Liu, 2015; Zhao et al., } \\
2018\end{array}$ & 7 \\
\hline & B06 Misunderstanding of BIM & $\begin{array}{l}\text { Khosrowshahi and Arayici, 2012; } \\
\text { Panuwatwanich and Peansupap, 2013; Zhang } \\
\text { et al., 2013; Lee et al., 2014; Chien et al., } \\
\text { 2014; Xu et al., 2014; Zhao et al., } 2018\end{array}$ & 7 \\
\hline & $\begin{array}{l}\text { B07 Negative Attitude towards } \\
\text { Working Collaboratively }\end{array}$ & $\begin{array}{l}\text { Dossick and Neff, 2010; Ku and Taiebat, } \\
\text { 2011; Arayici et al., 2012; Stanley and } \\
\text { Thurnell, 2014; Ozorhon and Karahan, 2016; } \\
\text { Jin et al., } 2017\end{array}$ & 6 \\
\hline & $\begin{array}{l}\text { B08 Lack of a Well-established } \\
\text { BIM-based Workflow }\end{array}$ & $\begin{array}{l}\text { Eastman et al., 2011; He et al., 2012; } \\
\text { Panuwatwanich and Peansupap 2013; Zhang } \\
\text { et al., 2013; Jin et al., } 2017\end{array}$ & 5 \\
\hline & $\begin{array}{l}\text { B09 Immature Dispute Resolution } \\
\text { Mechanisms for BIM } \\
\text { Implementation }\end{array}$ & $\begin{array}{l}\text { Pan and Zhao, 2012; He et al., 2012; Rezguil } \\
\text { et al., 2013; Liu and Liu, 2015; Xu and Kong, } \\
2016\end{array}$ & 5 \\
\hline \multirow{3}{*}{ Environmental } & $\begin{array}{l}\text { B10 Lack of Professional } \\
\text { Interactivity }\end{array}$ & $\begin{array}{l}\text { Mutai, 2009; Azhar 2011; He et al., 2012; } \\
\text { Zhang et al., 2013; Chien et al., 2014; Azhar et } \\
\text { al., 2015; Ding et al., 2015; Liu and Liu, 2015; } \\
\text { Ozorhon and Karahan, 2016; Xu and Kong, } \\
\text { 2016; Jin et al., } 2017\end{array}$ & 11 \\
\hline & $\begin{array}{l}\text { B11 Insufficient External } \\
\text { Motivation }\end{array}$ & $\begin{array}{l}\text { Adriaanse et al., 2010; Liu et al., 2010; Zhang } \\
\text { et al., 2013; Ding et al., 2015; Cao et al., 2015; } \\
\text { Xu and Kong, } 2016\end{array}$ & 6 \\
\hline & $\begin{array}{l}\text { B12 Lack of Research on BIM } \\
\text { Implementation in China }\end{array}$ & $\begin{array}{l}\text { Pan and Zhao, 2012; He et al., 2012; Zhang et } \\
\text { al., 2013; Zhang et al., } 2016\end{array}$ & 4 \\
\hline
\end{tabular}




\begin{tabular}{|c|c|c|c|}
\hline \multirow{4}{*}{ Financial } & $\begin{array}{l}\text { B13 Cost and Time Required for } \\
\text { Training }\end{array}$ & $\begin{array}{l}\text { Tse et at., 2005; Yan and Damian, 2008; } \\
\text { Suermann and Issa, 2009; Liu et al., 2010; } \\
\text { Zhang et al., 2013; Eadie et al., 2014; Xu et } \\
\text { al., 2014; Rogers et al., 2015; Ozorhon and } \\
\text { Karahan, 2016; Jin et al., } 2017\end{array}$ & 10 \\
\hline & $\begin{array}{l}\text { B14 Cost of BIM Experts and } \\
\text { Tools }\end{array}$ & $\begin{array}{l}\text { Suermann and Issa, 2009; Khosrowshahi and } \\
\text { Arayici, 2012; Pan and Zhao, 2012; Zhang et } \\
\text { al., 2013; Xu et al., 2014; Liu and Liu, 2015; } \\
\text { Xu and Kong, } 2016\end{array}$ & 7 \\
\hline & B15 Increased Design Costs & $\begin{array}{l}\text { Tse et at., 2005; Liu et al., 2010; Azhar et al., } \\
\text { 2011; Eastman et al., 2011; Pan and Zhao, } \\
\text { 2012; Lu et al., 2014; Liu and Liu, } 2015\end{array}$ & 7 \\
\hline & $\begin{array}{l}\text { B16 Ambiguous Economic } \\
\text { Benefits }\end{array}$ & $\begin{array}{l}\text { Barlish and Sullivan, 2012; Xu and Kong, } \\
\text { 2016; Jin et al., 2017; Papadonikolaki and } \\
\text { Aibinu, 2017; Zhao et al., } 2018\end{array}$ & 5 \\
\hline \multirow{4}{*}{ Legal } & $\begin{array}{l}\text { B17 Lack of Protection for } \\
\text { Intellectual Property Rights }\end{array}$ & $\begin{array}{l}\text { Ku and Taiebat, 2011; Azhar 2011; He et al., } \\
\text { 2012; Pan and Zhao, 2012; Rezguil et al., } \\
\text { 2013; Zhang et al., 2013; Fan, 2013; Azhar et } \\
\text { al., 2015; Liu and Liu, 2015; Hsu et al., 2015; } \\
\text { Ozorhon and Karahan, } 2016\end{array}$ & 11 \\
\hline & B18 Lack of BIM Standards & $\begin{array}{l}\text { Pan and Zhao, 2012; He et al., 2012; Zhang et } \\
\text { al., 2013; Chien et al., 2014; Stanley and } \\
\text { Thurnell, 2014; Zhang et al., 2014; Azhar et } \\
\text { al., 2015; Liu and Liu, 2015; Xu and Kong, } \\
\text { 2016; Jin et al., } 2017\end{array}$ & 10 \\
\hline & $\begin{array}{l}\text { B19 Lack of a Standard Form of } \\
\text { Contract for BIM Implementation }\end{array}$ & $\begin{array}{l}\text { Nawari, 2012; Zhang et al., 2013; Stanley and } \\
\text { Thurnell, 2014; Chien et al., 2014; Liu and } \\
\text { Liu, 2015; Hsu et al., 2015; Bui et al., 2016; } \\
\text { Xu and Kong, } 2016\end{array}$ & 8 \\
\hline & $\begin{array}{l}\text { B20 Lack of Insurance Applicable } \\
\text { to BIM Implementation }\end{array}$ & $\begin{array}{l}\text { Pan and Zhao, 2012; Eadie et al., 2014; Azhar } \\
\text { et al., 2015; Liu and Liu, 2015; } \\
\text { Ghaffarianhoseini et al., } 2017\end{array}$ & 5 \\
\hline
\end{tabular}

\section{B01 Difficulty in Adapting to the BIM Process}

Some studies, like Lu and Korman (2010) and Elmualim and Gilder (2014), found that one of the most serious challenges to BIM implementation in construction projects is the adaptation to BIM technology and processes. Stakeholders, especially those in a developing market, have to deal with the difficulty in effectively reengineering the existing process, which significantly constrains BIM implementation (Yan and Damian, 2008).

\section{B02 Lack of Domestic-oriented BIM Tools}

Existing BIM tools suited for construction projects in other countries or regions might not fit the context of China's prefabricated construction. Many of these tools cannot adapt to China's building codes or meet the requirements of local construction (Zhang et al., 2016; Pan and Zhao, 2012). Domestic-oriented BIM tools are thus urgently needed to overcome 
this barrier (Bui et al., 2016).

\section{B03 Increased Workload for Model Development}

Implementing BIM in prefabricated construction means a heavier workload when it comes to model development. For example, stakeholders have to spend extra time and effort ensuring the digital objects in a BIM model have the required level of development (Pan and Zhao, 2012). Thus, the extra workload will result in negative attitudes toward BIM implementation.

\section{B04 Resistance to Change}

The implementation of BIM unavoidably changes project delivery and potentially an organization's structure (Eastman et al., 2011). Stakeholders in the construction industry are known to be resistant to change. They are used to traditional paper-based methods and unwilling to adopt new technologies. Persuading these reluctant parties to use BIM can be extremely difficult (Arayici et al., 2011; Panuwatwanich and Peansupap, 2013; Yan and Damian, 2008).

\section{B05 Negative Attitude towards Data Sharing}

In a construction project where BIM is used, it is often the case that each stakeholder develops their own model for design and analysis by using their own preferred software. Stakeholders generally do not like to share data with each other. Considering the fact that an effective implementation of BIM needs collaboration and data integration through compatible if not the one particular software, negative attitudes towards data sharing affect the ultimate success of BIM implementation (Zhao et al., 2018).

\section{B06 Misunderstanding of BIM}

The performance of BIM-based projects depends on its stakeholders' properly understanding BIM (Khosrowshahi and Arayici, 2012). Misinterpreting BIM, its basic concept, applications, and process will ultimately hinder achieving all the potential benefits of BIM (Panuwatwanich and Peansupap, 2013) and lead to serious risks (Zhao et al., 2018).

\section{B07 Negative Attitude towards Working Collaboratively}

The ideal situation for BIM implementation includes an array of participants, such as the client, designer, engineer, and contractor, working collaboratively on a single integrated BIM model. However, the scope for such integration remains limited, and previous studies have reported stakeholders owning to negative attitudes towards working collaboratively (e.g., Arayici et al., 2012). The collaboration among stakeholders, in a BIM-based project, is thus an important, but challenging issue (Ozorhon and Karahan, 2016).

\section{B08 Lack of a Well-established BIM-based Workflow}


Up until now, there is no relevant document to help stakeholders in China formalize and standardize their BIM-based workflow for prefabricated construction. Stakeholders thus have to find their own way to deal with the existing separated and fragmented workflow, a considerable barrier to BIM implementation (Eastman et al., 2011; Panuwatwanich and Peansupap, 2013).

\section{B09 Immature Dispute Resolution Mechanisms for BIM Implementation}

BIM implementation may allow for the blurring of responsibility amongst stakeholders and thus prevent assigning individual liability when mistakes are made to the collective design. Moreover, when disputes related to BIM implementation happen, no mature mechanism is available in China for stakeholders to resolve the dispute, which seriously increases the risk of BIM implementation (Pan and Zhao, 2012).

\section{B10 Lack of Professional Interactivity}

The implementation of BIM requires professional interactivity in a constant and dynamic manner throughout a project. However, the current construction industry is universally known for its lack of professional interaction (Ozorhon and Karahan, 2016; Jin et al., 2017). This barrier could thus encumber the implementation of BIM in China's prefabricated construction.

\section{B11 Insufficient External Motivation}

External motivation has been identified as an important factor affecting BIM implementation (Ding et al., 2015). However, stakeholders in the construction industry generally do not have enough motivation to use BIM (Cao et al., 2015), and the incentive mechanism of BIM implementation in China has not been well established. Such insufficient external impetus will inhibit positive attitudes towards BIM.

\section{B12 Lack of Research on BIM Implementation in China}

It is generally uncommon for construction stakeholders to specifically research BIM for their projects due to time and resource constraints (Pan and Zhao, 2012). Some will simply copy BIM execution plans from external sources (Zhang et al., 2016). The limited study of BIM implementation, conducted within the context of China's prefabricated construction, could lead to a low-level of BIM adaptability and hinder actual BIM implementation.

\section{B13 Cost and Time Required for Training}

It is critical for stakeholders to be aware of the importance of training staff for BIM implementation (Suermann and Issa, 2009; Ozorhon and Karahan, 2016). Previous studies have confirmed stakeholders' concern about squandering time and money on labor training (Eadie et al., 2014), as well as under or overestimating the time and resources they have allocated for such training (Yan and Damian, 2008). In addition, stakeholders face risks 
related to the potential decrease in staff members' productivity due to the learning curve. Therefore, the cost and time required for training will hinder the BIM implementation.

\section{B14 Cost of BIM Experts and Tools}

The cost of BIM experts and tools is a serious issue for small to medium-sized enterprises (SMEs) since most usually have limited financial capacity to bear the initial investment in emerging digital technologies and hiring BIM experts (Khosrowshahi and Arayici, 2012; Suermann and Issa, 2009). Apart from the initial investment, looming BIM tools adds to SMEs' disinclination.

\section{B15 Increased Design Costs}

Compared with conventional methods, the use of BIM might increase costs during the design stage ( $\mathrm{Lu}$ et al., 2014), which increases the risk of BIM impeding profitability. The high front-end cost of BIM implementation in construction projects is regarded as a significant barrier (Azhar et al., 2011). Therefore, companies may choose not to use BIM unless they can have long-term benefits or related subsidies (Eastman et al., 2011).

\section{B16 Ambiguous Economic Benefits}

It is always necessary to understand the benefits of BIM implementation, including both tangible and intangible benefits (Barlish and Sullivan, 2012; Jin et al., 2017; Zhao et al., 2018). However, economic benefits brought by BIM are often ambiguous, which has been considered a key obstacle for its adoption (Papadonikolaki and Aibinu, 2017).

\section{B17 Lack of Protection for Intellectual Property Rights}

Many researchers worry about problems associated with intellectual property rights over BIM implementation, such as the BIM model ownership and data ownership contained within the model. Appropriate legislation protecting the IP rights is thus of great significance for BIM implementation (Ozorhon and Karahan, 2016; Pan and Zhao, 2012; Ku and Taiebat, 2011), but currently missing from China's construction industry.

\section{B18 Lack of BIM Standards}

Lack of standardization from authorities is a commonly encountered barrier towards BIM implementation (Pan and Zhao, 2012; Zhang et al., 2014; Jin et al., 2017). The execution of BIM relies on standards for governing its procedures, activities, and deliverables. Although recent years have witnessed a few BIM standards published by governmental agencies in China, the overall scope of BIM standards in the region is doubtlessly inadequate compared to the United States, Australia, and other OECD (Organization for Economic Co-operation and Development) countries. More seriously, no standard is currently available for BIM implementation in prefabricated construction. 


\section{B19 Lack of a Standard Form of Contract for BIM Implementation}

A new form of contract is needed to avoid potential arguments that are centered around BIM responsibilities and liabilities (Nawari, 2012; Bui et al., 2016). However, there is no such standard form of contract in China, obliging stakeholders to suffer uncertainty and conceivably spend additional time and money on dealing with the potential risks.

\section{B20 Lack of Insurance Applicable to BIM Implementation}

The implementation of BIM can bring new risks to stakeholders (Eadie et al., 2014). For example, the accuracy of the information contained in BIM entails substantial hazards. Inaccuracies result in poor decision making and additional time and costs spent addressing the consequent mistakes (Ghaffarianhoseini et al., 2017). Therefore, designing and securing insurance applicable to BIM implementation is necessary. Determining who is responsible for reviewing the information in BIM and what should be done if errors are found in the model should be standard practice in order to mitigate the potential risks. Lack of insurance applicable to deal with errors and problems within a BIM leads to enormous efforts spent on requesting and supplementing incomplete and inaccurate information.

\section{Identification of Key Barriers}

The barriers identified above were filtered further to obtain key BIM implementation barriers in China's prefabricated construction before ISM is conducted. Another reason for this filtering is that, for studies using ISM, usually twelve or fewer factors are considered. This is because the increase in the number of factors increases the complexity of the methodology (Attri et al., 2013). To filter the barriers, the authors issued a questionnaire survey to obtain opinions from industrial practitioners in China. The participants were asked to mark the seriousness of each BIM implementation barrier in China's prefabricated construction on a one to five scale, i.e., very slight, slight, moderate, serious, and very serious; valued as 1, 2, 3,4 , and 5 respectively.

A total of 80 questionnaires were distributed, and 32 valid responses were obtained (a response rate of $40 \%$ ). As present in Table 2, the respondents come from different companies in Guangdong, Beijing, Hubei, Chongqing, Shaanxi and other thirteen districts. All these respondents have over one year of experience in using BIM for prefabricated construction. Based on the practitioners' responses obtained from this questionnaire survey, the level of seriousness of each barrier was calculated by summing up the values given in the valid responses (see Figure 2). The twelve barriers with the highest scores, indicating they have relatively serious impact on BIM implementation in prefabricated construction, were screened out (see Table 3).

Table 2 Background information of respondents

\begin{tabular}{|l|c|c|c|c|}
\hline Employer & $\begin{array}{c}\text { Construction } \\
\text { company }\end{array}$ & $\begin{array}{c}\text { Design } \\
\text { company }\end{array}$ & $\begin{array}{c}\text { Real estate } \\
\text { company }\end{array}$ & $\begin{array}{c}\text { Research } \\
\text { institution }\end{array}$ \\
\hline
\end{tabular}




\begin{tabular}{|l|c|c|c|c|c|c|}
\hline Number & \multicolumn{2}{|c|}{14} & \multicolumn{2}{c|}{3} & \multicolumn{2}{c|}{$>$} \\
\hline $\begin{array}{l}\text { Year(s) of experience in using } \\
\text { BIM for prefabricated construction }\end{array}$ & \multicolumn{2}{|c|}{$1-3$} & \multicolumn{2}{|c|}{$4-6$} & \multicolumn{2}{|c|}{$>$} \\
\hline Number & \multicolumn{2}{|c|}{13} & & 9 & \multicolumn{2}{c|}{10} \\
\hline District of the respondent & Guangdong & Beijing & Hubei & Chongqing & Shaanxi & Others $^{*}$ \\
\hline Number & 7 & 4 & 4 & 2 & 2 & 13 \\
\hline
\end{tabular}

* Others consist of thirteen respondents from thirteen different districts.

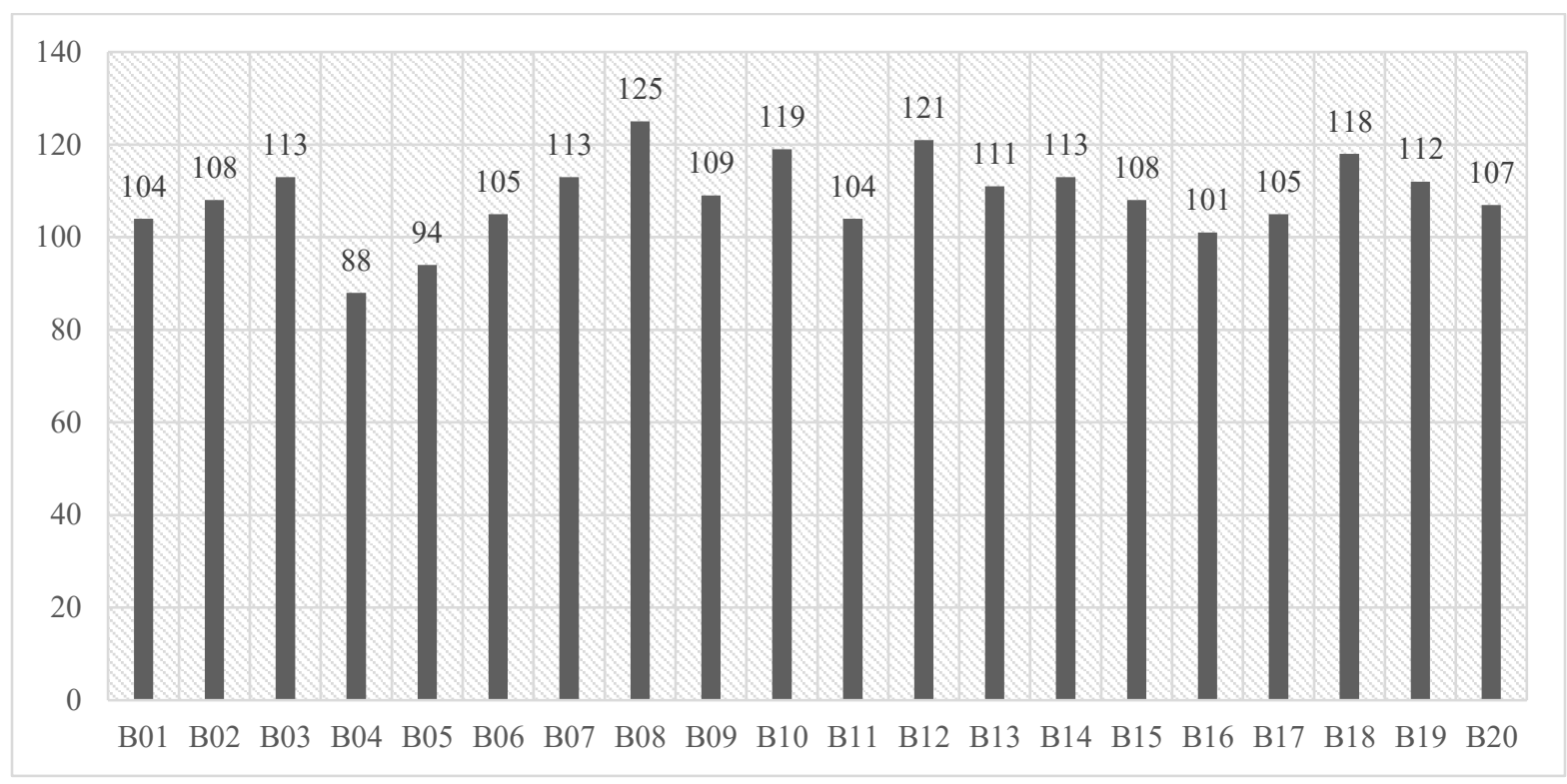

Figure 2 Scores of twenty barriers

Table 3 Barriers to BIM implementation in China's prefabricated construction

\begin{tabular}{|l|l|}
\hline No. & Barrier \\
\hline B02 & Lack of domestic-oriented BIM tools \\
\hline B03 & Increased workload for model development \\
\hline B07 & Negative attitude towards working collaboratively \\
\hline B08 & Lack of a well-established BIM-based workflow \\
\hline B09 & Immature dispute resolution mechanism for BIM implementation \\
\hline B10 & Lack of professional interactivity \\
\hline B12 & Lack of research on BIM implementation in China \\
\hline B13 & Cost and time required for training \\
\hline B14 & Cost for BIM experts and tools \\
\hline B15 & Increased design costs \\
\hline B18 & Lack of BIM standards \\
\hline B19 & Lack of standard form of contract for BIM implementation \\
\hline
\end{tabular}

\section{ISM Methodology}

Some techniques, such as Analytical Network Process (ANP) and ISM, are available to analyze the interrelationships among factors in a complex system. However, ANP cannot completely show all kinds of dependencies since it is generally difficult to obviate the 
possibility of interactions within the criteria cluster ( $\mathrm{Wu}, 2008)$. In contrast, ISM, developed by Warfield in 1974, enables insights into the direct and indirect interrelationships between various factors with ranking and direction (Thakkar et al., 2005; Attri et al., 2013). In the research field of construction management, ISM has been used to study factors affecting the productivity of construction workers (Sandbhor and Botre, 2014) and risks of the design phase of construction projects (Etemadinia and Tavakolan, 2018). Gan et al. (2018) also used ISM to explore the interactions among barriers to off-site construction in China, but they carried out their survey within the context of Chongqing, China and did not provide insights into the BIM implementation barriers in prefabricated construction. This study adopted ISM to generate the structural mapping of intricate interconnections of barriers to BIM implementation in China's prefabricated construction. Figure 3 shows the five essential steps of ISM methodology.

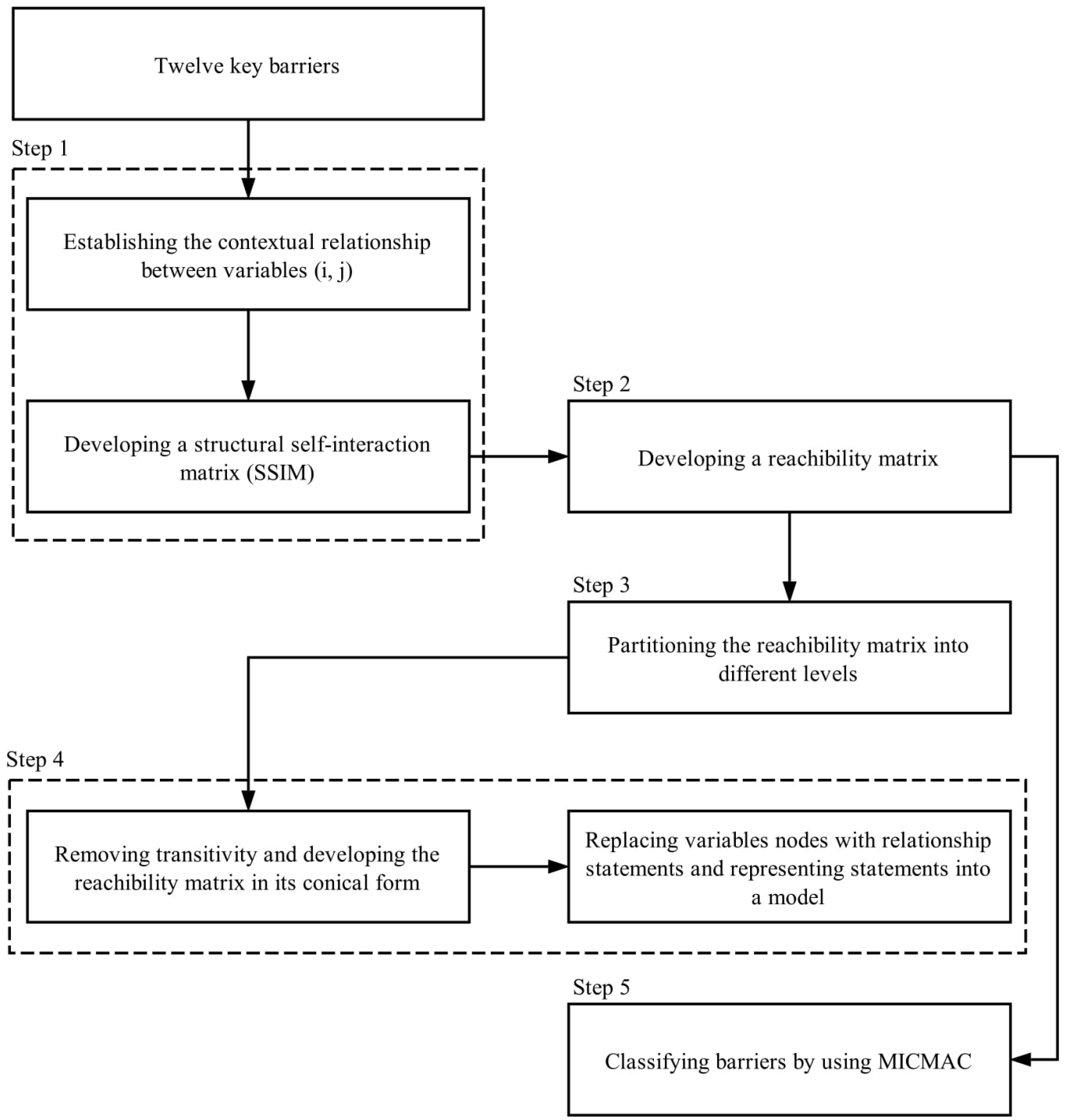

Figure 3 Process of implementing ISM in this study

\section{Step 1: Establishing Correlation Structure}

After finalizing the twelve barriers, semi-structured interviews with experts were conducted to ascertain experts' opinions about the interrelationships between these barriers. The authors 
contacted a total of twenty experts suitable for this interview through LinkedIn. The selection is based on the professional profiles and services of the potential interviewees in order to ensure only those with strong experience and knowledge in both BIM and prefabricated construction in China were invited to the interview. Five experts ultimately agreed to participate in the interview. Their profiles are shown in Table 4. All five experts were asked questions about the relationship between each two barriers. Due to the complexity and non-binding nature of the interviews, the collected answers were interpreted by the authors to find the contextual interrelationships among barriers and input the results into the Structural Self-Interaction Matrix (SSIM). In this study, the interrelationship between barriers $i$ and $j$ were represented by four symbols: (1) $W$ refers to "barrier $i$ can result in barrier $j$ but not vice versa"; (2) $X$ refers to "barrier $j$ can lead to barrier $i$ but not vice versa"; (3) $Y$ refers to "barriers $i$ and $j$ can lead to each other"; and (4) $Z$ refers to "barriers $i$ and $j$ are not related". In cases when different experts made different judgment towards the relationship of two barriers, the "minority gives way to the majority" principle was applied in order to determine the interrelationships.

Table 4 Background information of interviewed experts

\begin{tabular}{llllll}
\hline Expert & Occupation & Employer & Education & $\begin{array}{l}\text { Years of Work } \\
\text { Experience }\end{array}$ & $\begin{array}{l}\text { Years of Experience in Using BIM } \\
\text { for Prefabricated Construction }\end{array}$ \\
\hline A & Researcher & Research institution & Master & 20 & 8 \\
B & Engineer & Construction company & Bachelor & 3 & 2 \\
C & Manager & Design company & Master & 10 & 8 \\
D & Engineer & BIM service company & Bachelor & 5 & 5 \\
E & Architect & Design company & Bachelor & 7 & 4 \\
\hline
\end{tabular}

According to the feedback of the interviewed experts, contextual relationships among the twelve barriers were constructed (see Table 5). From Table 5, the close interrelationships between B07, B08, B09, B10, and B19 are evident. It is also worth noting that these five barriers all have frequent interactions with other barriers.

Table 5 Developed SSIM

\begin{tabular}{lllllllllllll}
\hline Barrier & B02 & B03 & B07 & B08 & B09 & B10 & B12 & B13 & B14 & B15 & B18 & B19 \\
\hline B19 & Z & Z & Z & Y & W & W & X & Z & Z & Z & X & - \\
B18 & Z & Z & Z & Z & W & W & X & Z & Z & Z & - & \\
B15 & Z & X & Z & Z & Z & X & Z & X & X & - & & \\
B14 & Z & Z & Z & Z & Z & Z & X & X & - & & & \\
B13 & Z & Z & Z & Z & Z & X & Z & - & & & & \\
B12 & W & Z & Z & Z & W & Z & - & & & & & \\
B10 & X & W & Y & Y & Y & - & & & & & & \\
B09 & Z & W & V & X & - & & & & & & & \\
B08 & Z & Z & Y & - & & & & & & & & \\
B07 & X & W & - & & & & & & & & & \\
B03 & X & - & & & & & & & & & & \\
B02 & - & & & & & & & & & & & \\
\hline
\end{tabular}




\section{Step 2: Reachability Matrix}

Substituting the four symbols, i.e., $W, X, Y$, and $Z$, by 1 and 0 as per the given case, the developed SSIM is then transferred into a binary matrix for further calculation and analysis (Tan, 2018). Table 6 shows the substitution rule adopted by this study. Specifically, when the symbol of the direction of correlations between two barriers is $W, X, Y$, and $Z$, the $(i, j)$ and $(j, i)$ of the reachability matrix are filled in as the corresponding numbers in Table 6. For instance, if (B03, B02) in the SSIM is $X$, the $(\mathrm{B} 03, \mathrm{~B} 02)$ in the reachability matrix will be 0 , and the (B02, B03) will be 1.

Table 6 Substitution rule

\begin{tabular}{|l|l|l|}
\hline \multirow{2}{*}{$\begin{array}{l}\text { SSIM } \\
(i, j)\end{array}$} & Reachability Matrix \\
\cline { 2 - 3 } & $(i, j)$ & $(j, i)$ \\
\hline $\mathrm{W}$ & 1 & 0 \\
\hline $\mathrm{X}$ & 0 & 1 \\
\hline $\mathrm{Y}$ & 1 & 1 \\
\hline $\mathrm{Z}$ & 0 & 0 \\
\hline
\end{tabular}

Following the rule given in Table 6, an initial reachability matrix is developed illustrating the interrelationships between each two of the twelve barriers. Next, the indirect transferability of these barriers is calculated in an open-sourced online platform

(http://www.huaxuejia.cn/ism/cal ism in_all.php) to generate the final reachability matrix as shown in Table 7 . The transitivity rules were assessed by conducting a power iteration analysis. In Table 7, entry la represents incorporating transitivity. For example, (B09, B19) is 1a, which means that there is an indirect relationship between B09 (Immature dispute resolution mechanism for BIM implementation) and B19 (Lack of standard form of contract for BIM implementation).

Table 7 Reachability matrix (Including initial and final)*

\begin{tabular}{|l|l|l|l|l|l|l|l|l|l|l|l|l|l|}
\hline Barrier & B02 & B03 & B07 & B08 & B09 & B10 & B12 & B13 & B14 & B15 & B18 & B19 & Driving power \\
\hline B02 & 1 & 1 & 1 & $1 \mathrm{a}$ & $1 \mathrm{a}$ & 1 & 0 & $1 \mathrm{a}$ & $1 \mathrm{a}$ & $1 \mathrm{a}$ & 0 & $1 \mathrm{a}$ & 10 \\
\hline B03 & 0 & 1 & 0 & 0 & 0 & 0 & 0 & 0 & 0 & 1 & 0 & 0 & 2 \\
\hline B07 & 0 & 1 & 1 & 1 & $1 \mathrm{a}$ & 1 & 0 & $1 \mathrm{a}$ & $1 \mathrm{a}$ & $1 \mathrm{a}$ & 0 & $1 \mathrm{a}$ & 9 \\
\hline B08 & 0 & $1 \mathrm{a}$ & 1 & 1 & 1 & 1 & 0 & $1 \mathrm{a}$ & $1 \mathrm{a}$ & $1 \mathrm{a}$ & 0 & 1 & 9 \\
\hline B09 & 0 & 1 & 1 & $1 \mathrm{a}$ & 1 & 1 & 0 & $1 \mathrm{a}$ & $1 \mathrm{a}$ & $1 \mathrm{a}$ & 0 & $1 \mathrm{a}$ & 9 \\
\hline B10 & 0 & 1 & 1 & 0 & 1 & 1 & 0 & 1 & $1 \mathrm{a}$ & 1 & 0 & $1 \mathrm{a}$ & 8 \\
\hline B12 & 1 & $1 \mathrm{a}$ & $1 \mathrm{a}$ & $1 \mathrm{a}$ & 1 & $1 \mathrm{a}$ & 1 & $1 \mathrm{a}$ & 1 & $1 \mathrm{a}$ & 1 & 1 & 12 \\
\hline B13 & 0 & 0 & 0 & 0 & 0 & 0 & 0 & 1 & 1 & 1 & 0 & 0 & 3 \\
\hline B14 & 0 & 0 & 0 & 0 & 0 & 0 & 0 & 0 & 1 & 1 & 0 & 0 & 2 \\
\hline B15 & 0 & 0 & 0 & 0 & 0 & 0 & 0 & 0 & 0 & 1 & 0 & 0 & 1 \\
\hline B18 & 0 & $1 \mathrm{a}$ & $1 \mathrm{a}$ & $1 \mathrm{a}$ & 1 & 1 & 0 & $1 \mathrm{a}$ & $1 \mathrm{a}$ & $1 \mathrm{a}$ & 1 & 1 & 10 \\
\hline B19 & 0 & $1 \mathrm{a}$ & $1 \mathrm{a}$ & 1 & 1 & 1 & 0 & $1 \mathrm{a}$ & $1 \mathrm{a}$ & $1 \mathrm{a}$ & 0 & 1 & 9 \\
\hline Dependence power & 2 & 9 & 8 & 7 & 8 & 8 & 1 & 9 & 10 & 12 & 2 & 8 & \\
\hline
\end{tabular}

* 1 a indicates the indirect influence relationship between barriers in considering the transitivity. 


\section{Step 3: Level Partitions}

The final reachability matrix was used to identify the reachability and antecedent sets of every barrier and form the level partitions. The reachability set comprises each specific barrier and any other barriers it may lead to, should there be any, while the antecedent set contains each specific barrier and other barriers, again should there be any, that may result. Afterwards, the intersection of the reachability and antecedent sets is derived for all barriers. The barriers for which the reachability set and the intersection are the same occupy the top level of the ISM hierarchy, indicating that these barriers would very likely be affected by other barriers. Once the barrier at the top level is identified, it will be removed from the reachability set of other barriers. Then, this process is repeated to obtain barriers at the next level and will not stop until all barriers are placed in the ISM hierarchy. Table 8 presents the results of level partitions.

Table 8 Results of level partitions

\begin{tabular}{|c|c|c|c|c|}
\hline Barrier & Reachability Set & Antecedent Set & Intersection & Level \\
\hline B02 & $\begin{array}{l}\text { B02; B03; B07; B08; B09; B10; } \\
\text { В13; B14; B15; B19 }\end{array}$ & B02; B12 & B02 & $\mathrm{V}$ \\
\hline B03 & B03; B15 & $\begin{array}{l}\text { B02; B03; B07; B08; B09; B10; } \\
\text { В12; B18; B19 }\end{array}$ & B03 & III \\
\hline B07 & $\begin{array}{l}\text { B03; B07; B08; B09; B10; B13; } \\
\text { B14; B15; B19 }\end{array}$ & $\begin{array}{l}\text { B02; B07; B08; B09; B10; B12; } \\
\text { B18; B19 }\end{array}$ & $\begin{array}{l}\text { B07; B08; B09; } \\
\text { B10; B19 }\end{array}$ & IV \\
\hline B08 & $\begin{array}{l}\text { B03; B07; B08; B09; B10; B13; } \\
\text { В14; B15; B19 }\end{array}$ & $\begin{array}{l}\text { B02; B07; B08; B09; B12; B18; } \\
\text { B19 }\end{array}$ & $\begin{array}{l}\text { B07; B08; B09; } \\
\text { B19 }\end{array}$ & IV \\
\hline B09 & $\begin{array}{l}\text { B03; B07; B08; B09; B10; B13; } \\
\text { В14; B15; B19 }\end{array}$ & $\begin{array}{l}\text { B02; B07; B08; B09; B10; B12; } \\
\text { В18; B19 }\end{array}$ & $\begin{array}{l}\text { B07; B08; B09; } \\
\text { B10; B19 }\end{array}$ & IV \\
\hline B10 & $\begin{array}{l}\text { B03; B07; B09; B10; B13; B14; } \\
\text { B15; B19 }\end{array}$ & $\begin{array}{l}\text { B02; B07; B08; B09; B10; B12; } \\
\text { B18; B19 }\end{array}$ & $\begin{array}{l}\text { B07; B09; B10; } \\
\text { B19 }\end{array}$ & IV \\
\hline B12 & $\begin{array}{l}\text { B02; B03; B07; B08; B09; B10; } \\
\text { В12; B13; B14; B15; B18; B19 }\end{array}$ & B12 & B12 & VI \\
\hline B13 & B13; B14; B15 & $\begin{array}{l}\text { B02; B07; B08; B09; B10; B12; } \\
\text { B14; B18; B19 }\end{array}$ & B14 & III \\
\hline B14 & B14; B15 & $\begin{array}{l}\text { B02; B07; B08; B09; B10; B12; } \\
\text { B13; B14; B18; B19 }\end{array}$ & B14 & II \\
\hline B15 & B15 & $\begin{array}{l}\mathrm{B} 02 ; \mathrm{B} 03 ; \mathrm{B} 07 ; \mathrm{B} 08 ; \mathrm{B} 09 ; \mathrm{B} 10 \\
\mathrm{~B} 12 ; \mathrm{B} 13 ; \mathrm{B} 14 ; \mathrm{B} 15 ; \mathrm{B} 18 ; \mathrm{B} 19\end{array}$ & B15 & I \\
\hline B18 & $\begin{array}{l}\text { B03; B07; B08; B09; B10; B13; } \\
\text { В14; B15; B18; B19 }\end{array}$ & B12; B18 & B18 & V \\
\hline B19 & $\begin{array}{l}\text { B03; B07; B08; B09; B10; B13; } \\
\text { В14; B15; B19 }\end{array}$ & $\begin{array}{l}\text { B02; B07; B08; B09; B10; B12; } \\
\text { В18; B19 }\end{array}$ & $\begin{array}{l}\text { B07; B08; B09; } \\
\text { B10; B19 }\end{array}$ & IV \\
\hline
\end{tabular}

\section{Step 4: Formation of ISM Diagraph and Model}

Based on the results of level partitions, the twelve barriers were positioned in the initial diagraph to present the chain of influence of barriers (see Figure 4). The initial diagraph 
illustrating the interrelationships between barriers. An arrow points from barrier $i$ to barrier $j$, showing that barrier $i$ can result in barrier $j$, and a two-way arrow indicates a mutual influence. These inter-influence relationships between barriers are expressed by transitivity; both direct and indirect transitivity links are contained in the diagram. Then, the diagraph was transferred to the ISM model by changing the nodes with statements (see Figure 5). The twelve barriers were separated into six levels of the ISM model.

Results shown in Table 8 and Figure 5 declare that the lack of research on BIM implementation in China (B12), especially the limited research about how to make BIM suitable for prefabricated construction in China's local context, is the most fundamental barrier in the structure hierarchy. This finding suggested that the implementation of BIM in China's prefabricated construction should seriously consider the unique market environment of China. Additionally, the lack of BIM standards (B18) and the lack of domestic-oriented BIM tools (B02) reside at Level V, relating to the operation and technology supports for fostering a suitable cooperation environment. Barriers at Level IV, such as the negative attitude towards working collaboratively (B07) and the immature dispute resolution mechanism for BIM implementation (B09), are related to the workflow and cooperation situation. Barriers B07 and B09 could be alleviated directly by overcoming barriers at Level V. The remaining four barriers, including B03 and B13 at Level III, B14 at Level II, and B15 at Level I, are related to the additional investment and time required by the implementation of BIM.

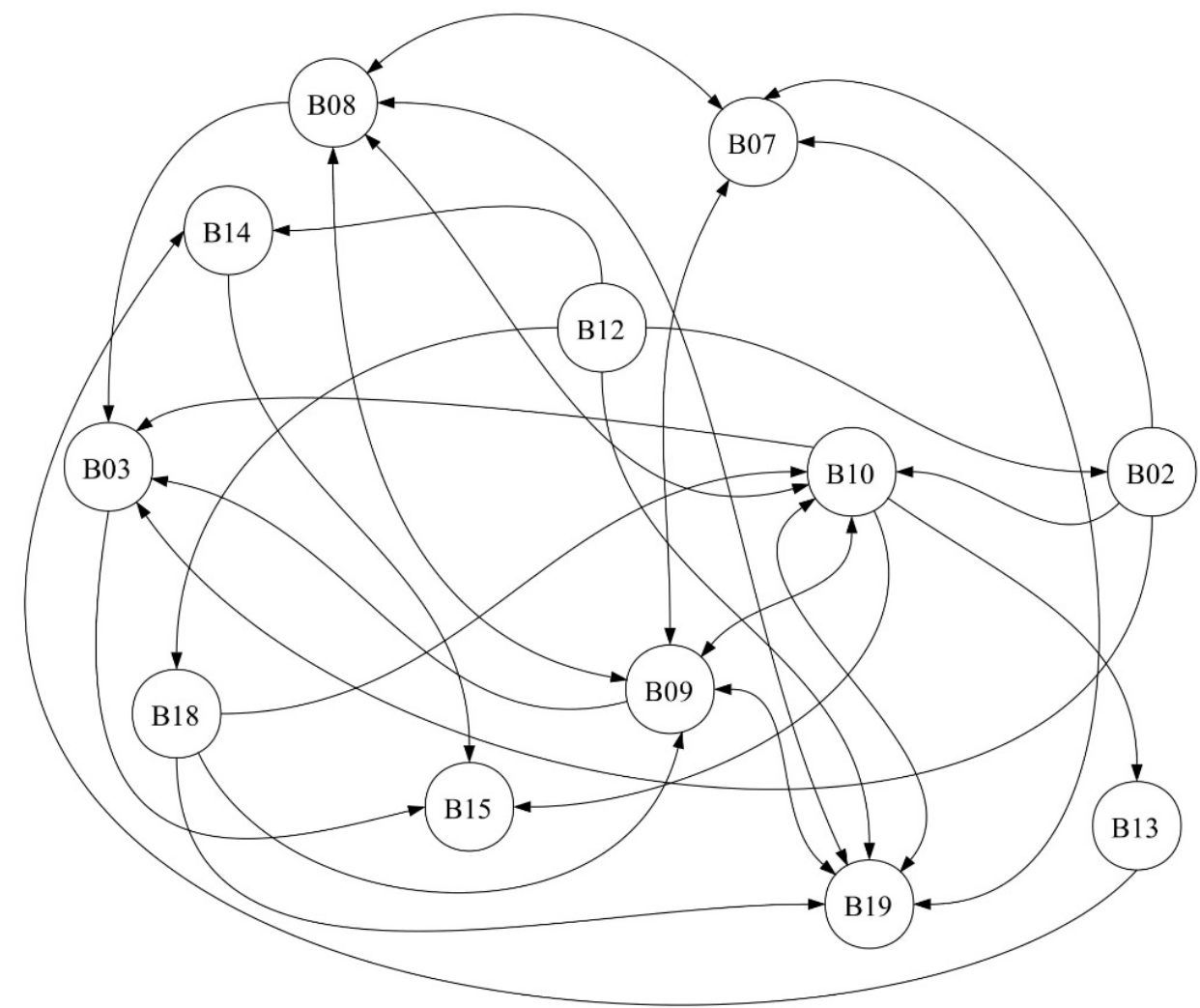

Figure 4 Interrelationships between twelve barriers 


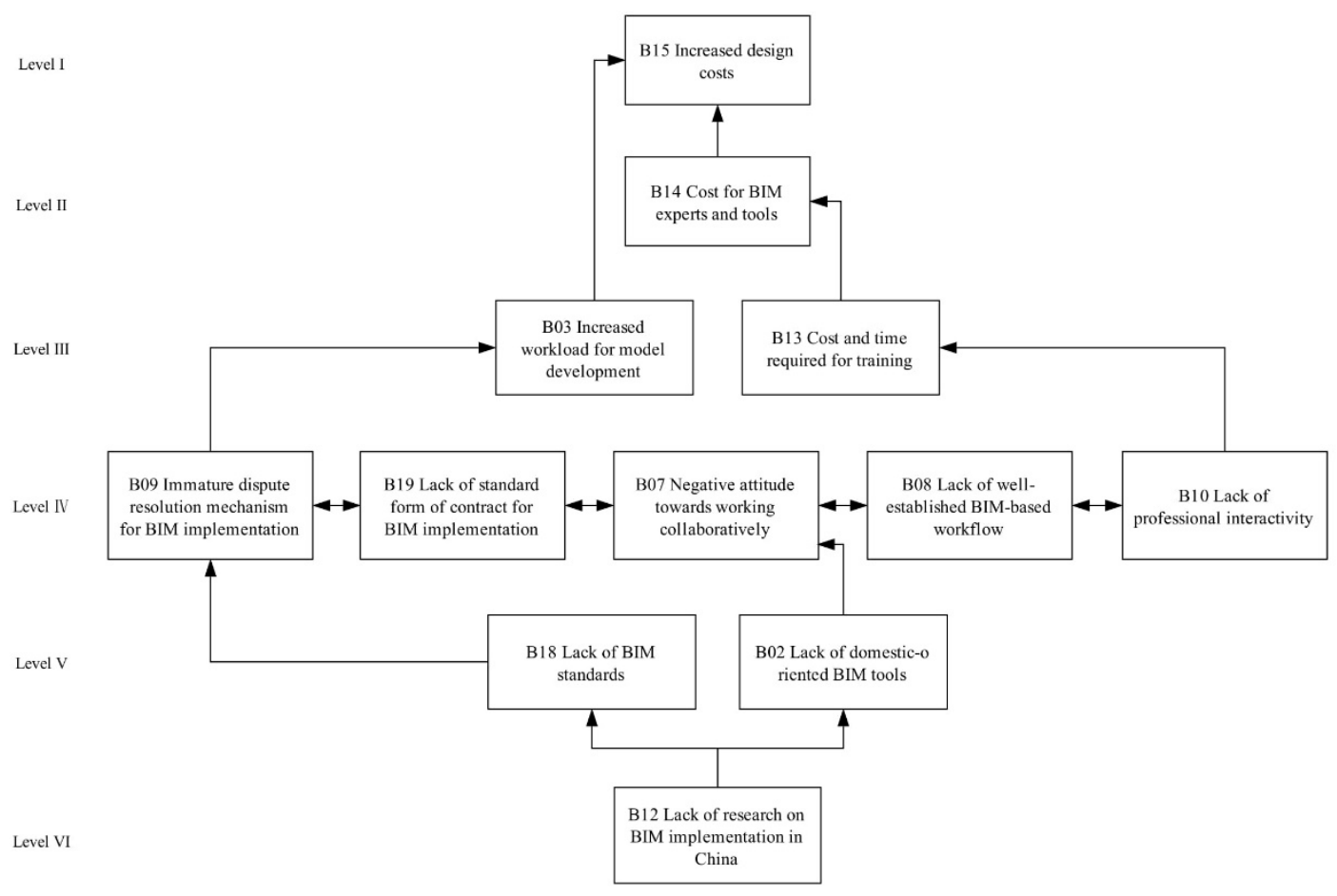

Figure 5 ISM model of barriers to BIM implementation in China's prefabricated construction

\section{Step 5: Classification of Barriers}

These twelve barriers are classified by transforming the reachability matrix (see Table 7) into a MICMAC diagram, which helps evaluate the driving and dependence powers of BIM implementation barriers in prefabricated construction. In general, a barrier with a higher dependence power indicates that several other barriers should be addressed before this barrier can be eliminated. A barrier with a higher driving power means that its elimination allows the solving of several other barriers (Attri et al., 2013). Following the classification adopted by previous researchers (Mandal and Deshmukh, 1994), the barriers are divided into four groups, namely (1) autonomous variables where both driving and dependence powers are low; (2) dependent variables where driving power is low but dependence power is high; (3) driver variables where driving power is high but dependence power is low; and (4) linkage variables where both driving and dependence powers are high.

Figure 6 shows the results from the MICMAC analysis of the twelve barriers. General observations concerning the classification of barriers are presented as follows:

- B12 (Lack of research on BIM implementation in China) possesses the highest driving power but the lowest dependence power. This barrier thus has the strongest capability to influence other barriers and should be placed as the highest priority to address.

- B15 (Increased design costs) possesses the lowest driving power but the highest dependence power. Therefore, this barrier can be judged as the unfavorable outcome of other barriers.

- No barrier is identified to be an autonomous variable, which indicates that all twelve 
barriers can hinder the implementation of BIM in China's prefabricated construction in a more or less manner.

- Five barriers, i.e., B07, B08, B09, B10, and B19, are identified to be the linkage variables. This observation indicates that any action directed at these five barriers can affect other barriers, as well as have a feedback influence on themselves.

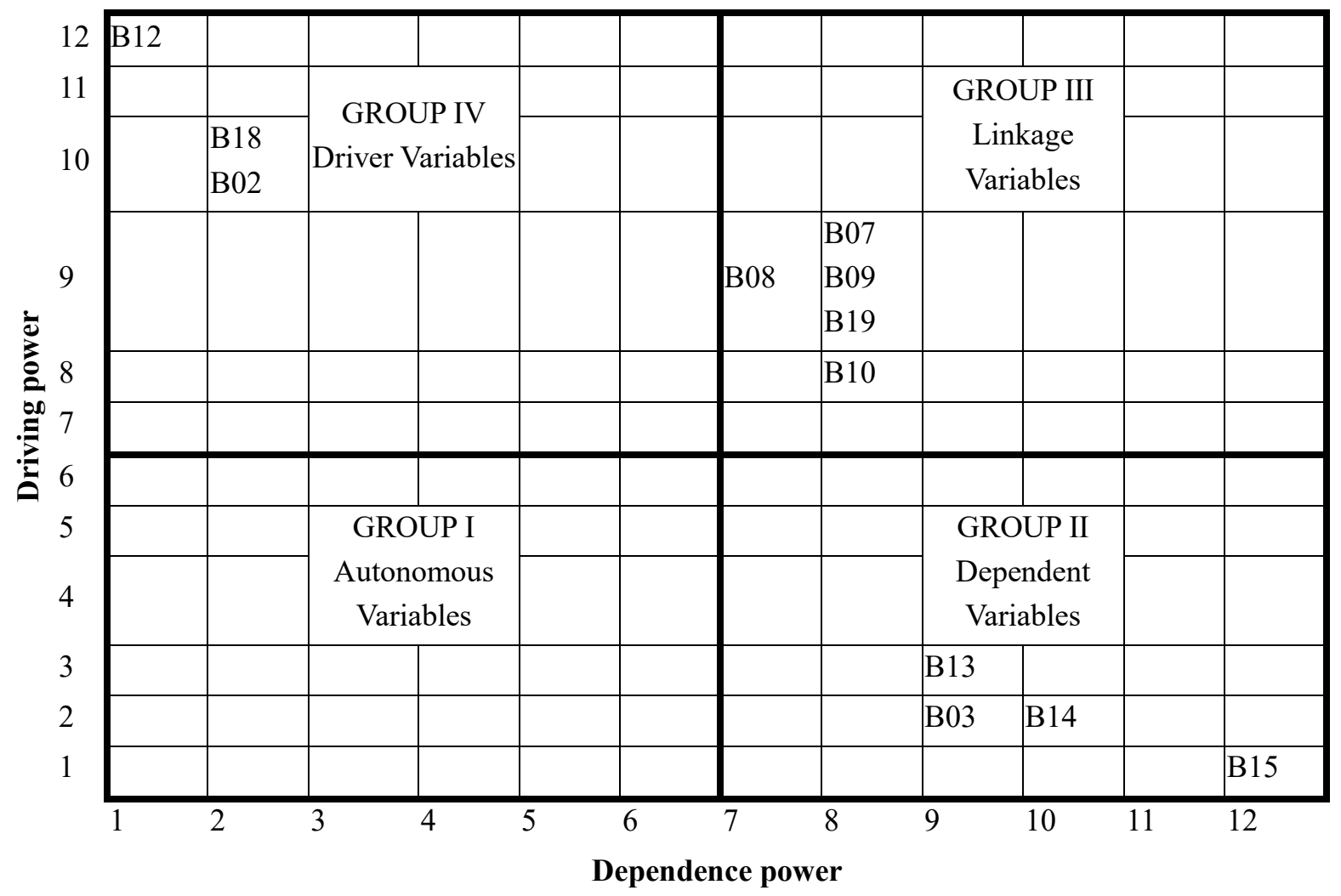

Figure 6 Results of MICMAC analysis of barriers

\section{Discussion}

\subsection{Comparison with previous studies}

It is worth noting that findings from the hierarchical structure are different from those reported in previous studies investigating barriers to BIM implementation in the construction industry. For instance, Eadie et al. (2014) suggested that the legal issue was not among the top five barriers to BIM implementation. A lack of domestic-oriented BIM tools was also not a commonly-reported BIM implementation barrier. In addition, some studies, such as Yan and Damian (2008) and Suermann and Issa (2009), considered the cost-related issue to be among the most serious barriers to BIM implementation, while this study found that issue less significant. Such differences could be better explained through the triangulation with the feedback of the five interviewed experts.

The discrepancy in the seriousness of cost-related barriers is possibly explained by the different value theories behind these two types of construction methods, i.e., in-situ construction and off-site prefabrication. The different characteristics of these two methods require various delivery methods, building workflows, and coordination relationships, which 
lead to different levels of importance for each type of barrier. One expert suggested that the weighting of initial BIM investment in prefabricated construction is relatively lower than in conventional in-situ construction because the investment in prefabrication is already much more expensive, nearly five to ten times, than the investment in BIM implementation.

Theoretically, BIM can facilitate the delivery of prefabricated construction, helping to save cost by decreasing potential waste and rework. Therefore, the relatively cheap investment in $\mathrm{BIM}$, together with the potential to optimize the delivery process and save on the total cost of prefabricated construction, makes cost-related barriers less serious than other key barriers identified in this study.

Compared with cost-related barriers, the lack of research on BIM implementation in China and the absence of standards and domestic-oriented tools deserve much more attention. Four experts expressed that the governmental agencies or professional institutions in developed countries like the United State and Australia have published a series of BIM standards for guiding the actual implementation. However, the development of BIM standards in China remains in the initial stage. No BIM standard specifically established for prefabricated construction is in place. Additionally, most of the BIM software adopted in China, such as Autodesk Revit, does not provide tailor-made functions for prefabricated construction. As noted by all of the interviewed experts, the lack of standards and domestic-oriented tools makes it difficult for industry practitioners to adapt to BIM implementation. These barriers are extremely serious in China where many industry practitioners hesitate to use BIM and take a wait-and-see attitude. Two experts further emphasized that the development of standards and tools needs a solid theoretical foundation, which requires researchers' investigation but suffers from a notable lack of contextualization for China's prefabricated construction. This explains the dominant position of B12 (lack of research on BIM implementation in China) in the hierarchical structure shown in Figure 5.

\subsection{Recommendations for BIM Implementation in China's Prefabricated Construction}

The identified interrelationships between twelve barriers help to propose a three-level strategy to promote BIM implementation in China's prefabricated construction (see Figure 7). At the first and fundamental level, the strategy should focus on barriers at Levels V and VI. Relevant research into BIM implementation in China's prefabricated construction should be gradually executed by the academia. The research could focus on how to drive the BIM implementation to fit the local context. In addition, relevant BIM standards should be developed by the governmental agencies, which help software developers propose domesticoriented BIM tools and guide stakeholders of a prefabricated construction project when proposing their BIM implementation plan (Nawari, 2012).

At the second level, the strategy should aim to address barriers at Level IV. The focus here is to let organizations develop an appropriate ecosystem for BIM implementation (Poerschke et 
al., 2010). Establishing mature workflows and mechanisms are urgently needed for the enterprise. Individuals should seek to absorb knowledge and skills regarding BIM through continuous training and education. Training programs focused on actual practices of different BIM responsibilities can quickly raise the BIM competence of a company. Cultivating an effective and tech-friendly working environment for BIM implementation is anticipated. Since the barriers at Level IV are linked, successfully overcoming them can feed back to the strategy for the first level and develop the strategy for the third level.

At the third level, the strategy should focus on enhancing the value-for-money of BIM implementation in prefabricated construction projects. One good example is to apply lean thinking in BIM implementation. Lean thinking is expected to improve the management of project time and cost. Many scholars have emphasized the combination of the two concepts, i.e. BIM and lean (Sacks et al., 2010; Zhang et al., 2018), to improve the project performance. Equipped with lean thinking, it could be more likely for stakeholders to resolve the barriers at Levels III, II, and I gradually. 


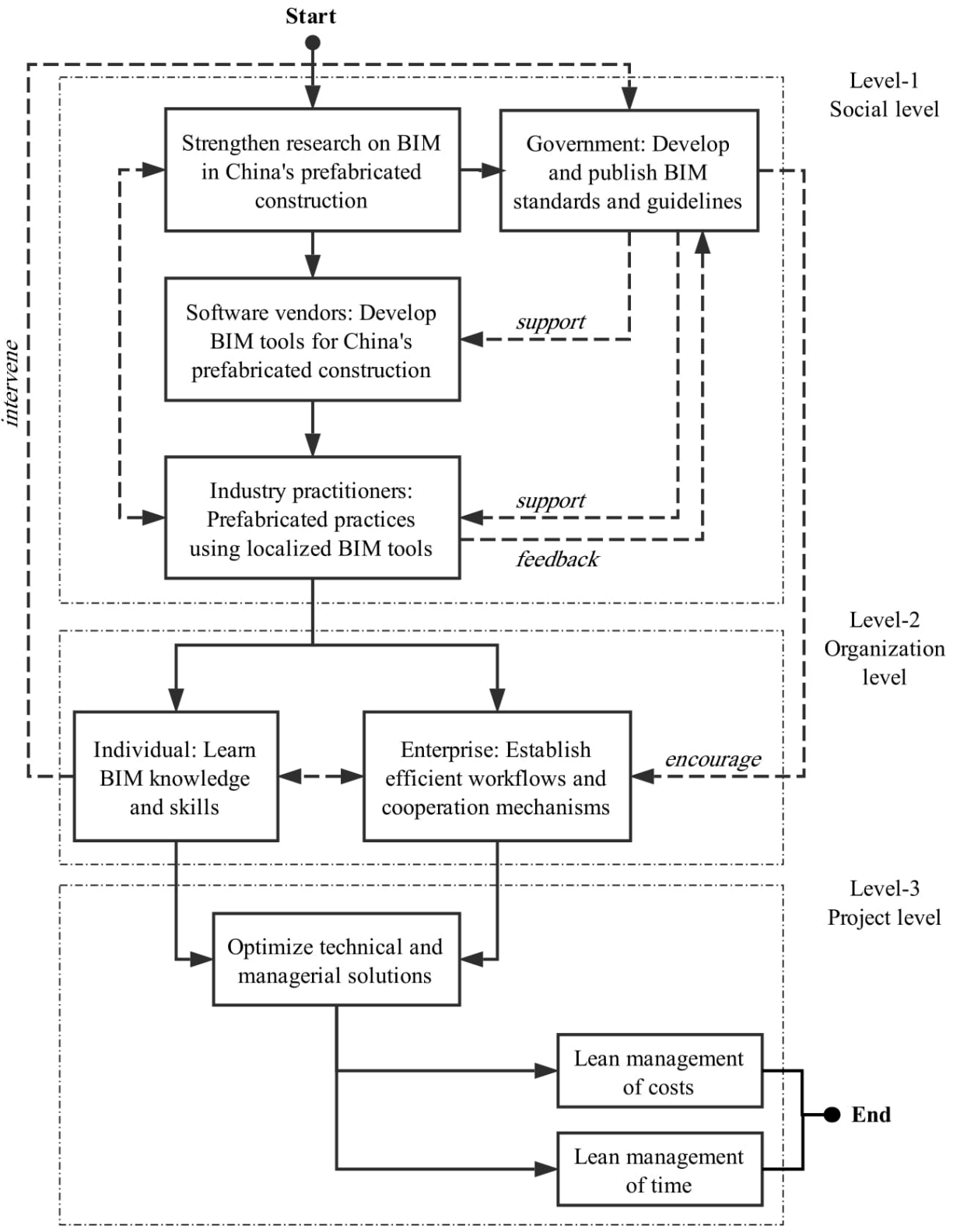

Figure 7 Recommended three-level strategy for multiple stakeholders

\section{Conclusion}

The urgent need for industry upgrading and the emergence of information technology provide a favorable opportunity for implementing BIM in prefabricated construction. However, the BIM implementation in China's prefabricated construction still remains in its infancy. This study contributes to the knowledge body by providing an in-depth understanding of interactive relationships among barriers affecting BIM implementation in China's prefabricated construction. It first identified twelve barriers to BIM implementation in China's prefabricated construction, and then applied ISM to structure the barriers in a hierarchy of six distinct levels. In addition, by applying MICMAC, the twelve barriers are classified into three driver variables, four dependent variables, and five linkage variables according to their driving and dependence powers. Findings of this study discovered the 
nature of interrelationships among the identified barriers, based on which a three-level strategy is recommended to facilitate BIM implementation in China's prefabricated construction.

Although the context of this study is China, this research has two major implications for the global construction industry. First, this research unleashes the facts that it is unlikely to reach a single set of BIM implementation barriers to all situations. In other words, different situations (e.g., developed or developing countries; in-situ or prefabricated construction) will face different structures of BIM implementation barriers. In this regard, the methods illustrated in this research could provide a useful reference for other economies that aim to investigate the interrelationships between their own BIM implementation barriers. Second, the findings of this research suggested that the promotion of BIM implication in prefabrication construction requires multiple levels of strategies. Conducting more BIM research and developing relevant BIM standards and tools are of fundamental importance for countries or districts, like China, where BIM implementation is still at its infancy stage. For those where BIM standards and tools are more mature, more attention should be paid to establishing standardized organization-level BIM work process and further enhancing the value-for-money of BIM implementation in prefabricated construction.

Significant as it is, this study still has two main limitations that should not be overlooked. First, BIM implementation in prefabricated construction faces a sundry of different barriers. Nevertheless, this study does not and cannot consider all barriers mentioned by previous studies in order to avoid the increasing complexity of the ISM methodology. Thus, barriers with less significance were not included in the analysis. Second, the reported analytical results are not statistically validated. Therefore, future research is suggested to integrate other analytical methods to assess the validity of the hypothetical model proposed in this study.

\section{Acknowledgments}

This paper derives from the MSc dissertation written by the first author entitled "Correlations between BIM implementation barriers in China's prefabricated buildings: an interpretive structural modeling approach" supervised by Dr. Grant Mills at University College London. Special thanks to all editors and reviewers for their constructive comments. Special thanks to Ms. Anna Zetkulic for her proofreading.

\section{References}

Adriaanse, A., Voordijk, H., \& Dewulf, G. (2010). The use of interorganisational ICT in United States construction projects. Automation in Construction, 19(1), 73-83.

Arayici, Y., Coates, P., Koskela, L., Kagioglou, M., Usher, C., \& O'reilly, K. (2011). Technology adoption in the BIM implementation for lean architectural 
practice. Automation in Construction, 20(2), 189-195.

Arayici, Y., Egbu, C. O., \& Coates, S. P. (2012). Building information modelling (BIM) implementation and remote construction projects: issues, challenges, and critiques. Journal of Information Technology in Construction, 17, 75-92.

Attri, R., Dev, N., \& Sharma, V. (2013). Interpretive structural modelling (ISM) approach: an overview. Research Journal of Management Sciences, 2319, 1171.

Azhar, S. (2011). Building information modeling (BIM): Trends, benefits, risks, and challenges for the AEC industry. Leadership and Management in Engineering, 11(3), 241-252.

Azhar, S., Khalfan, M., \& Maqsood, T. (2015). Building information modelling (BIM): now and beyond. Construction Economics and Building, 12(4), 15-28.

Barlish, K., \& Sullivan, K. (2012). How to measure the benefits of BIM-A case study approach. Automation in Construction, 24, 149-159.

Bui, N., Merschbrock, C., \& Munkvold, B. E. (2016). A review of Building Information Modelling for construction in developing countries. Procedia Engineering, 164, 487494.

Cao, D., Wang, G., Li, H., Skitmore, M., Huang, T., \& Zhang, W. (2015). Practices and effectiveness of building information modelling in construction projects in China. Automation in Construction, 49, 113-122.

Chen, K., Lu, W., Peng, Y., Rowlinson, S., \& Huang, G. Q. (2015). Bridging BIM and building: From a literature review to an integrated conceptual framework. International Journal of Project Management, 33(6), 1405-1416.

Chen, K., Xu, G., Xue, F., Zhong, R. Y., Liu, D., \& Lu, W. (2018). A physical internetenabled building information modelling system for prefabricated construction. International Journal of Computer Integrated Manufacturing, 31(4-5), 349361.

Chien, K. F., Wu, Z. H., \& Huang, S. C. (2014). Identifying and assessing critical risk factors for BIM projects: Empirical study. Automation in Construction, 45, 1-15.

Ding, Z., Zuo, J., Wu, J., \& Wang, J. Y. (2015). Key factors for the BIM adoption by architects: A China study. Engineering, Construction and Architectural Management, 22(6), 732-748.

Dossick, C. S., \& Neff, G. (2009). Organizational divisions in BIM-enabled commercial construction. Journal of Construction Engineering and Management, 136(4), 459-467.

Eadie, R., Odeyinka, H., Browne, M., McKeown, C., \& Yohanis, M. (2014). Building information modelling adoption: an analysis of the barriers to implementation. Journal of Engineering and Architecture, 2(1), 77-101.

Eastman, C., Teicholz, P., Sacks, R., \& Liston, K. (2011). BIM handbook: A guide to building information modeling for owners, managers, designers, engineers and contractors. John Wiley \& Sons.

Elmualim, A., \& Gilder, J. (2014). BIM: innovation in design management, influence and 
challenges of implementation. Architectural Engineering and Design Management, 10(3-4), 183-199.

Etemadinia, H., \& Tavakolan, M. (2018). Using a hybrid system dynamics and interpretive structural modeling for risk analysis of design phase of the construction projects. International Journal of Construction Management, 1-20.

Fan, S. L. (2013). Intellectual property rights in building information modeling application in Taiwan. Journal of Construction Engineering and Management, 140(3), 04013058.

Gan, X., Chang, R., Zuo, J., Wen, T., \& Zillante, G. (2018). Barriers to the transition towards Off-site construction in China: An Interpretive Structural Modeling approach. Journal of Cleaner Production, 197, 8-18.

Ghaffarianhoseini, A., Tookey, J., Ghaffarianhoseini, A., Naismith, N., Azhar, S., Efimova, O., \& Raahemifar, K. (2017). Building Information Modelling (BIM) uptake: Clear benefits, understanding its implementation, risks and challenges. Renewable and Sustainable Energy Reviews, 75, 1046-1053.

Gu, N., \& London, K. (2010). Understanding and facilitating BIM adoption in the AEC industry. Automation in Construction, 19(8), 988-999.

He, Q. H., Qian, L. L., Duan, Y. F., \& Li, Y. K. (2012). Current situation and barriers of BIM implementation. Gong Cheng Guan Li Xue Bao [Journal of Engineering Management], 26(1), 12-16. (in Chinese with English abstract)

Hong, J., Shen, G. Q., Li, Z., Zhang, B., \& Zhang, W. (2018). Barriers to promoting prefabricated construction in china: A cost-benefit analysis. Journal of Cleaner Production, 172, 649-660.

Hsu, K. M., Hsieh, T. Y., \& Chen, J. H. (2015). Legal risks incurred under the application of BIM in Taiwan. Proceedings of the Institution of Civil Engineers-Forensic Engineering, 168(3), 127-133.

Jaillon, L., Poon, C. S., \& Chiang, Y. H. (2009). Quantifying the waste reduction potential of using prefabrication in building construction in Hong Kong. Waste Management, 29(1), 309-320.

Jiang, R., Mao, C., Hou, L., Wu, C., \& Tan, J. (2018). A SWOT analysis for promoting offsite construction under the backdrop of China's new urbanisation. Journal of Cleaner Production, 173, 225-234.

Jin, R., Gao, S., Cheshmehzangi, A., \& Aboagye-Nimo, E. (2018). A Holistic Review of offsite Construction Literature Published between 2008 and 2018. Journal of Cleaner Production, 202, 1202-1219.

Jin, R., Hancock, C. M., Tang, L., \& Wanatowski, D. (2017). BIM investment, returns, and risks in China's AEC industries. Journal of Construction Engineering and Management, 143(12), 04017089.

Khosrowshahi, F., \& Arayici, Y. (2012). Roadmap for implementation of BIM in the UK construction industry. Engineering, Construction and Architectural Management, 19(6), 610-635. 
Ku, K., \& Taiebat, M. (2011). BIM experiences and expectations: The constructors' perspective. International Journal of Construction Education and Research, 7(3), 175197.

Lee, S. K., Kim, K. R., \& Yu, J. H. (2014). BIM and ontology-based approach for building cost estimation. Automation in Construction, 41, 96-105.

Li, C. Z., Zhong, R. Y., Xue, F., Xu, G., Chen, K., Huang, G. G., \& Shen, G. Q. (2017). Integrating RFID and BIM technologies for mitigating risks and improving schedule performance of prefabricated house construction. Journal of Cleaner Production, 165, 1048-1062.

Liu, R., Issa, R., \& Olbina, S. (2010). Factors influencing the adoption of building information modeling in the AEC Industry. In Proceedings of the International Conference on Computing in Civil and Building Engineering (pp. 139-145).

Liu, B., \& Liu, W. (2015). Application Status and Obstacles Research of BIM in Domestic Construction Industry. Jian Zhu Jing Ji [Construction Economy], 36(9), 20-23. (in Chinese with English abstract)

Lu, N., \& Korman, T. (2010). Implementation of building information modeling (BIM) in modular construction: Benefits and challenges. In Construction Research Congress 2010: Innovation for Reshaping Construction Practice (pp. 1136-1145).

Lu, W., Chen, K., Xue, F., \& Pan, W. (2018). Searching for an optimal level of prefabrication in construction: An analytical framework. Journal of Cleaner Production, 201, 236-245.

Lu, W., Fung, A., Peng, Y., Liang, C., \& Rowlinson, S. (2014). Cost-benefit analysis of Building Information Modeling implementation in building projects through demystification of time-effort distribution curves. Building and Environment, 82, 317327.

Mandal, A., \& Deshmukh, S.G. (1994). Vendor selection using interpretive structural modelling (ISM). International Journal of Operations \& Production Management, 14(6), 52-59.

Mehran, D. (2016). Exploring the adoption of BIM in the UAE construction industry for AEC Firms. Procedia Engineering, 145, 1110-1118.

Mutai, A. (2009). Factors influencing the use of building information modeling (BIM) within leading construction firms in the United States of America (Doctoral dissertation, Indiana State University).

Nawari, N. O. (2012). BIM standard in off-site construction. Journal of Architectural Engineering, 18(2), 107-113.

Ozorhon, B., \& Karahan, U. (2016). Critical success factors of building information modeling implementation. Journal of Management in Engineering, 33(3), 04016054.

Panuwatwanich, K., \& Peansupap, V. (2013). Factors affecting the current diffusion of BIM: a qualitative study of online professional network. In Creative Construction Conference, Budapest, Hungary (pp. 6-9).

Pan, J. Y., \& Zhao, Y. Y. (2012). Research on barriers of BIM application in China's building 
industry. Gong Cheng Guan Li Xue Bao [Journal of Engineering Management], 26(1), 6-11. (in Chinese with English abstract)

Papadonikolaki, E., \& Aibinu, A. (2017). The influence of leadership, resources and organisational structure on BIM adoption. In Proceedings of the 33rd Annual ARCOM Conference (Vol. 33).

Poerschke, U., Holland, R. J., Messner, J. I., \& Pihlak, M. (2010). BIM collaboration across six disciplines. In Proceedings of the International Conference on Computing in Civil and Building Engineering (pp. 575-671).

Rezgui, Y., Beach, T., \& Rana, O. (2013). A governance approach for BIM management across lifecycle and supply chains using mixed-modes of information delivery. Journal of Civil Engineering and Management, 19(2), 239-258.

Rogers, J., Chong, H. Y., \& Preece, C. (2015). Adoption of building information modelling technology (BIM) perspectives from Malaysian engineering consulting services firms. Engineering, Construction and Architectural Management, 22(4), 424-445.

Sacks, R., Koskela, L., Dave, B. A., \& Owen, R. (2010). Interaction of lean and building information modeling in construction. Journal of Construction Engineering and Management, 136(9), 968-980.

Sandbhor, S. S., \& Botre, R. P. (2014). Applying total interpretive structural modeling to study factors affecting construction labour productivity. Construction Economics and Building, 14(1), 20-31.

Stanley, R., \& Thurnell, D. P. (2014). The benefits of and barriers to implementation of 5D BIM for quantity surveying in New Zealand. Construction Economics and Building, 14(1), 105-117.

Suermann, P. C., \& Issa, R. R. (2009). Evaluating industry perceptions of building information modelling (BIM) impact on construction. Journal of Information Technology in Construction, 14(37), 574-594.

Tam, V. W., Tam, C. M., Zeng, S. X., \& Ng, W. C. (2007). Towards adoption of prefabrication in construction. Building and Environment, 42(10), 3642-3654.

Tan, T. (2018). Correlations between BIM implementation barriers in China's prefabricated buildings: an interpretive structural modeling approach. Master thesis, University College London.

Thakkar, J., Deshmukh, S. G., Gupta, A. D., \& Shankar, R. (2005). Selection of third-party logistics (3PL): a hybrid approach using interpretive structural modeling (ISM) and analytic network process (ANP). In Supply Chain Forum: An International Journal (Vol. 6, No. 1, pp. 32-46). Taylor \& Francis.

Tse, T. C. K., Wong, K. D. A., \& Wong, K. W. F. (2005). The utilisation of building information models in $\mathrm{nD}$ modelling: a study of data interfacing and adoption barriers. Journal of Information Technology in Construction, 10(8), 85-110.

Won, J., Lee, G., Dossick, C., \& Messner, J. (2013). Where to focus for successful adoption of building information modeling within organization. Journal of Construction 
Engineering and Management, 139(11), 04013014.

Wu, W. W. (2008). Choosing knowledge management strategies by using a combined ANP and DEMATEL approach. Expert Systems with Applications, 35(3), 828-835.

$\mathrm{Xu}, \mathrm{H} .$, Feng, J., \& Li, S. (2014). Users-orientated evaluation of building information model in the Chinese construction industry. Automation in Construction, 39, 32-46.

$\mathrm{Xu}, \mathrm{Y}$., \& Kong, Y. (2016). Analysis of the influence factors of application and promotion of BIM in China. Gong Cheng Guan Li Xue Bao [Journal of Engineering Management], 32(2), 28-32. (in Chinese with English abstract)

Xue, F., Chen, K., Lu, W., Niu, Y., \& Huang, G. Q. (2018). Linking radio-frequency identification to Building Information Modeling: Status quo, development trajectory and guidelines for practitioners. Automation in Construction, 93, 241-251.

Yan, H., \& Damian, P. (2008). Benefits and barriers of building information modelling. In Proceedings of the 12th International Conference on Computing in Civil and Building Engineering.

Zhang, L., Li, Y., \& Gao, Y. (2013). Barrier and countermeasures of the BIM application in China. Tu Mu Gong Cheng Yu Guan Li Xue Bao [Journal of Civil Engineering and Management], 30(3), 65-69. (in Chinese with English abstract)

Zhang, J., Long, Y., Lu, S., \& Xiang, Y. (2016). BIM-enabled modular and industrialized construction in China. Procedia Engineering, 145, 1456-1461.

Zhang, L., Wang, G., Chen, T., \& He, G. (2014). Survey of BIM application status and characteristics in China. In Proceedings of the 17th International Symposium on Advancement of Construction Management and Real Estate (pp. 969-979). Springer, Berlin, Heidelberg.

Zhang, X., Azhar, S., Nadeem, A., \& Khalfan, M. (2018). Using Building Information Modelling to achieve Lean principles by improving efficiency of work teams. International Journal of Construction Management, 18(4), 293-300.

\section{Figure captions}

Figure 1 Research flow

Figure 2 Scores of twenty barriers 
Figure 3 Process of implementing ISM in this study

Figure 4 Interrelationships between twelve barriers

Figure 5 ISM model of barriers to BIM implementation in China's prefabricated construction Figure 6 Results of MICMAC analysis of barriers

Figure 7 Recommended three-level strategy for multiple stakeholders 